\title{
Un-signing Geneva: legal pragmatics in the management of asylum
}

\author{
Marc de Leeuw ${ }^{1 \star}$ and Sonja van Wichelen ${ }^{2}$ \\ ${ }^{1}$ Senior Lecturer, Faculty of Law, University of New South Wales (UNSW), Law Building, Room 330, Sydney, NSW 2052 , \\ Australia and ${ }^{2}$ Senior Lecturer, Department of Sociology and Social Policy (SSPS/FASS), University of Sydney, Room 106, RC \\ Mills Building (A26), Sydney NSW, 2006, Australia \\ ${ }^{*}$ Corresponding author. E-mail: m.deleeuw@unsw.edu.au
}

\begin{abstract}
In the last decade, several states have increasingly tried to 'un-sign' to their humanitarian obligations by seeking ways to circumvent European or international law. Through an analysis of a recently passed act in Australia on the management of asylum seekers, this paper examines how the practice of 'un-signing' can be seen as a symptomatic instance of reconfiguring asylum in late modernity. We focus on the proliferation of 'legal pragmatics' in the management of refugees. By 'legal pragmatics', we refer to the processual ways in which the state attempts to hollow out international refugee law and in which courts respond by reinstating it. Normative consequences are the criminalisation and the juridification of refugees. We argue that the proliferation of 'legal pragmatics' illuminates not only the ever-expanding reach of neoliberal changes in domestic legislation, but also the limitations of human rights to adequately respond to the neoliberal vicissitudes of humanitarian government.
\end{abstract}

Keywords: asylum; refugees; humanitarian government; legal pragmatics; globalisation; Australia

\section{Introduction}

'I'll rip up human rights laws that impede new terror legislation.' (Theresa May ${ }^{1}$ )

'For the cost of resettling one refugee in the United States, we can assist more than ten in their home region.' (Donald Trump ${ }^{2}$ )

'[The Bill] is all about saying we will decide who gets permanent visas, we will decide who gets turned back, and we will decide where that decision is made in Australia under our laws, not out of the directives of Geneva or elsewhere.' (Scott Morrison ${ }^{3}$ )

It was only a few decades ago - particularly after the fall of the Berlin Wall - that globalisation, Europeanisation and the accompanying ideas of cosmopolitanism were prevalent if not celebratory amongst politicians in European and American states. International and European human rights principles were increasingly finding their ways into domestic applications and humanitarian clauses were

\footnotetext{
${ }^{1}$ Available at https://www.theguardian.com/politics/2017/jun/06/theresa-may-rip-up-human-rights-laws-impede-new-terror-legislation (accessed 29 May 2018).

${ }^{2}$ Available at https://www.washingtonpost.com/news/fact-checker/wp/2017/09/22/president-trumps-claim-that-10-refugees-overseas-cost-as-much-as-one-in-the-u-s/?utm_term=.1bc34ee2e27b (accessed 29 May 2018).

${ }^{3}$ Available at http://www.smh.com.au/federal-politics/political-news/scott-morrison-invokes-john-howard-in-challenginglabor-to-back-temporary-protection-visas-20141026-11c0kk.html\#ixzz3HJWfsDTe (accessed 29 May 2018). Also see https:// museumvictoria.com.au/immigrationmuseum/discoverycentre/identity/people-like-them/the-white-picket-fence/john-howards2001-federal-election-policy-launch-speech/ (accessed 29 May 2018).
}

(C) Cambridge University Press 2018 
written into conventions while Member States signed onto them. Today, we witness an increasing retreat from such commitments. At the same time as international human rights instruments are gaining traction in domestic and European courts, politicians are finding ways to limit 'as-much-as-legally-possible' their obligations to international law. It has come to the situation, we argue, that states and their actors are gradually 'un-signing' to international human rights. This phenomenon of 'un-signing', though, is rarely absolute: politicians do not actually up their allegiances to human rights or international law. Rather, they hollow it out so that they can pursue their political and economic interests on the one hand, while keeping their moral stature as a liberal democratic nation on the other. What are we to make of this phenomenon? How do law and legality figure in this political playing field? And what kind of consequences can be identified for the refugee?

Drawing from perspectives in socio-legal studies, cultural sociology and legal anthropology, our paper examines this recent move of 'un-signing' by looking at an empirical case in Australia. In December 2014, the Australian government introduced the so-called 'Migration and Maritime Powers Legislation Amendment (Resolving the Asylum Legacy Caseload) Act 2014', which we will refer to in this paper as the Legacy Caseload Act. ${ }^{4}$ This act was introduced by the coalition government to focus on asylum seekers who - between August 2012 and December 2013 - had arrived by boat and who were not relocated to offshore processing centres on Nauru or Manus Island. It proposed a number of significant changes to the existing organisation of asylum in Australia - in particular in its determination of legal refugee-hood. Among the changes suggested by the act are: granting the minister more removal power; the introduction of temporary protection visas that limit or exclude applications for permanent visas; a cap on protection visas in general; and the removal of a special status for children born in Australia after unauthorised arrival, equating them with adult asylum seekers.

The Legacy Caseload Act is extraordinary in that it clearly tries to move away from Australia's protective obligations as set out by the non-refoulement (non-return) principles in international law and, more generally, from the well-established doctrines of the 1951 Geneva Convention relating to the status of the refugee. ${ }^{5}$ In what follows, we will unpack the main components of the act's proposals (Schedules 2 and 5 to the act) and focus particularly on how they construct the figure of the asylum seeker while minimising - or abolishing - references to the Geneva Convention.

Rather than positing questions around the legal tenets of the convention or the normative structures of its implementation, this paper posits the sociological question of how states are 'un-signing' and the political-philosophical question of what lies behind this move to 'un-sign'. Our analysis focuses on the proliferation of what we call a 'legal pragmatics' in the management of asylum. By 'legal pragmatics', we refer to the processual ways in which the state attempts to hollow out international refugee law and in which courts respond by reinstating it. Two deviating forces follow from these processes: the criminalisation and the juridification of the refugee. Whereas her legitimacy is increasingly predicated on economic paradigms, the refugee can only speak through the legal instruments provided to her. Ultimately, we argue that the proliferation of legal pragmatics illuminates not only the ever-expanding reach of neoliberal changes in domestic legislation, but also that it reveals the limitations of international refugee law - or human rights in general - to adequately respond to the neoliberal vicissitudes of humanitarian government.

\section{Debating the Asylum Legacy Caseload}

The Migration and Maritime Powers Legislation Amendment (Resolving the Asylum Legacy Caseload) Act 2014 introduced by the Australian coalition government deals with the so-called 'Asylum Legacy Caseload', which refers to the backlog of protection claims by asylum seekers who arrived unauthorised by boat between August 2012 and December 2013, of whom some were

\footnotetext{
${ }^{4}$ See http://www.aph.gov.au/Parliamentary_Business/Bills_Legislation/Bills_Search_Results/Result?bId=r5346 (accessed 29 May 2018).

${ }^{5}$ See Crock and Bones (2015, p. 2) for a concise genealogy of the United Nations Convention relating to the Status of Refugees (the 'Refugee Convention').
} 
transferred to offshore processing centres on Nauru or Manus Island in Papua New Guinea, while others were transferred back to Australia for processing. We will focus on two of the six amendments implemented by the act: Schedule 2, which deals with visas, and Schedule 5, which deals with references pertaining to international law.

The proposal in Schedule 2 concerns the reintroduction of the so-called Temporary Protection Visa (TPV) and the introduction of a new visa called the Safe Haven Enterprise Visa (SHEV). ${ }^{6}$ The reintroduction of the TPVs (granted for a maximum of three years) would prevent asylum seekers from obtaining permanent residency or citizenship. More specifically, people granted this visa will be barred from ever making a valid application for a permanent visa. Although they would be allowed to work and have access to social security or Medicare, they will not have access to family reunion or the right to re-enter Australia should they travel overseas.

The SHEV (granted for a maximum of five years) concerns a new visa that will be available to people from the legacy case-load who are found to be refugees, and who will be required to live in a 'designated region' and encouraged to fill job vacancies in regional areas. Those who can show they have worked in a regional area without accessing income support for three and a half years will be permitted to apply for other onshore visas, such as family and skilled visas (but not permanent protection visas). They would have the same restrictions on family reunion and re-entry to Australia as TPV holders.

Responding to queries from the media about the Bill (before it passed and became the act), the Australian minister for immigration, Scott Morrison, invoked the words of former Prime Minister John Howard when he explained that the newly proposed Bill on Asylum was

'all about saying we will decide who gets permanent visas, we will decide who gets turned back, and we will decide where that decision is made in Australia under our laws, not out of the directives of Geneva or elsewhere. ${ }^{7}$

Notwithstanding the debate of who defines the cultural contours of the Australian 'we', the point Morrison makes is about regaining the powers to have control over the admittance of refugees in Australia. It is about recovering decisions back to the sovereign state so that they (the executive), rather than some abstract law (the judiciary), can determine which people are most beneficial to Australia. For countries in the Global North, including Australia, this benefit is predominantly defined through economic values.

This economic stance is consolidated in the act by the introduction of the new SHEV, which expects from the recognised refugee that $s /$ he 'earns' her or his citizenship. It has to be beneficial to Australia and deploying labour to the regional areas of Australia, where there is a shortage in labour attending to the mining business, asylum seekers can make themselves useful and earn their ways to becoming a member of Australian society, although, even then, as the minister stresses, it will still be difficult to get permanent residency:

'Our experience on resettlement for people in this situation [SHEV] would mean that this is a very high bar to clear. Good luck to them if they choose to do that and if they achieve it. But if they do achieve it, then what we are doing here is not providing a pathway to welfare, and generational welfare at that. There is an opportunity here but I think it is a very limited opportunity and we will see how it works out. But at the end of the day, no-one is getting a permanent protection visa (Morrison, 26 September 2014). ${ }^{, 8}$

\footnotetext{
${ }^{6}$ See Schedules 2 and 5 to the act, which can be found at https://www.legislation.gov.au/Details/C2014A00135 (accessed 29 May 2018).

${ }^{7}$ Available at http://www.smh.com.au/federal-politics/political-news/scott-morrison-invokes-john-howard-in-challenginglabor-to-back-temporary-protection-visas-20141026-11c0kk.html\#ixzz3HJWfsDTe (accessed 29 May 2018). Also see https:// museumvictoria.com.au/immigrationmuseum/discoverycentre/identity/people-like-them/the-white-picket-fence/john-howards2001-federal-election-policy-launch-speech/ (accessed 29 May 2018).

${ }^{8}$ Available at http://www.minister.immi.gov.au/media/sm/2014/sm218131.htm (accessed 29 May 2018).
} 
Such economic (as well as paternalist and parochial) language has been commonplace in the communication of deterrence in Australia. Statements such as 'good luck to them', 'we're taking the sugar off the table ${ }^{10}$ and the use of strong language such as 'flood gates' in describing the arrival of refugees conjure highly economised (and masculinised) rhetoric in managing asylum. The persistence of such rhetoric in politics and media normalises deterrence politics in the public arena. It also pushes the idea that it is up to the executive government, rather than domestic or international jurisprudence, to decide upon the fate of refugees. This is made strikingly evident in the discussion on the act's relation vis-à-vis the Geneva Convention.

In Schedule 5 to the act, changes have been implemented that minimise Australia's obligation vis-à-vis international law. ${ }^{11}$ Besides removing literal references to the 1951 Refugees Convention, the changes would formalise that Australia's non-refoulement (non-return) obligations under international law are irrelevant for the purposes of removing unlawful non-citizens. It also proposes a new statutory framework to arrange the government's interpretation of its international obligations towards assessing asylum seekers. One of such interpretations relates to the definition of 'well-founded fear' and proposes that asylum seekers will be deemed not to have a 'well-founded fear' if they can relocate to another place in their country, change their occupation and/or modify their behaviour so as to avoid persecution. It is proposed that it will no longer be a requirement that the decisionmaker assess whether it is reasonable for them to do so. While this does not formally ignore Articles 31 and 33 of the 1951 UN Convention and 1967 Protocol relating to the status of refugees, it deeply undermines its core intentions. ${ }^{12}$

The coalition government explained their proposal in their Statement of Compatibility with Human Rights:

'While on the face of the legislation as proposed to be amended, these provisions are capable of authorizing actions which may not be consistent with Australia's non-refoulement obligations, the Government intends to continue to comply with these obligations and Australia remains bound by them as a matter of international law. They will not, however, be capable as a matter of domestic law of forming the basis of an invalidation of the exercise of the affected powers. It is the Government's position that the interpretation and application of such obligations is, in this context, a matter for the executive government. ${ }^{, 13}$

Here, the Australian government attempts to displace judicial power in the matter of asylum. While the government's desire to avoid the court could be regarded by some as entering the space of non-law, lawlessness or just a less generous interpretation of existing law, this feature, as we will argue in the next section, denotes instead a legal novelty and is part of what we call 'legal pragmatics' in the management of asylum. ${ }^{14}$

\footnotetext{
${ }^{9}$ Ibid.

${ }^{10}$ See http://www.theguardian.com/australia-news/2014/nov/19/scott-morrison-resettlement-indonesia-sugar-table (accessed 29 May 2018).

${ }^{11}$ They can be summed up as (1) insert a provision into the Migration Act that states that Australia's non-refoulement (non-return) obligations under international law are irrelevant for the purposes of removing unlawful non-citizens (Items 1,2), (2) remove references to the 1951 Refugees Convention (Items 10, 14, 15 amongst others) and (3) insert a new statutory framework to codify the government's interpretation of its international obligations towards assessing asylum seekers (Items 7-12). See pp. 17-23 of http://www.aph.gov.au/Parliamentary_Business/Bills_Legislation/Bills_Search_Results/Result? bId=r5346 (accessed 29 May 2018) and the Andrew and Renate Kaldor Centre for International Refugee Law Legislative Brief on the Act, available at http://www.kaldorcentre.unsw.edu.au/publication/legislative-brief-migration-and-maritimepowers-legislation-amendment-resolving-asylum (accessed 29 May 2018).

${ }^{12}$ Article 31 refers to the equal treatment of refugees regardless of how they entered the country and Art. 33 refers to the right not to be returned to a country where they may be persecuted (the non-refoulement principle).

${ }^{13}$ Statement of Compatibility with Human Rights, Migration and Maritime Powers Legislation Amendment (Resolving the Asylum Legacy Caseload) Bill 2014, p. 7, accessed 20 November 2014.

${ }^{14} \mathrm{We}$ thank one of the anonymous reviewers for suggesting clarification of this point.
} 


\section{On picking commas: the legal pragmatics of 'un-signing'}

Instructive for our discussion on legal pragmatics is the following exchange, as described in the Sydney Morning Herald (14 November 2014), between the liberal senator Ian Macdonald and a member of the Migration Institute of Australia, Nicholas Tebbey ${ }^{15}$ :

'Macdonald asked Tebbey why the government was introducing the legislation. Tebbey said: "Australia doesn't want to feel like it is beholden to a 1951 convention any longer."

Macdonald interjected, and told the inquiry: "No, it doesn't want to be beholden to the high court who will pick every comma in the wrong place to allow someone in."

"That's the purpose of it. If what we deal with are refugees who we used to deal with through UNHCR [United Nations High Commissioner for Refugees] in an ordered way, none of this will be important”.' (Sydney Morning Herald, 14 November 2014, emphasis added)

Macdonald's interjection reveals a number of things. First, it suggests that the state's 'un-signing' cannot entirely be equated with a complete rejection of their humanitarian obligations under international law. This means that - in principle - the state stands by their commitment to the Geneva Convention, underscoring the importance of the Geneva Convention for the nation's moral standing. Second, it reveals the extent to which 'boat people' - as the category of refugees who are not coming in an orderly fashion through the UNHCR channels - are seen as an exceptional case, deserving of scrutiny and stringent observation, rather than compassion and hospitality. Finally, it concerns an indictment of the courts - in particular the High Court - and discloses the tensions that have been culminating in the past few decades between the powers of the executive and the powers of the judiciary.

The separation of powers in the political configuration of the asylum question reveals a politicolegal playing field in which the pro-border-protection executive stands against the pro-Geneva Convention judiciary. Both institutional parties would attest and critique the other party of politicising law - a forceful claim in light of the conventional assumption that law operates outside of conventional politics. On the one hand, contemporary politics of border control - across the political spectrum increasingly attempt to legalise their approach in domestic law despite contradictory principles of protection that states have signed themselves up for. On the other, although it is testing for the courts to implement international law (and most refugee cases involve statutory construction or constitutional interpretation), some important cases in the past that were brought to the High Court have proven the executive in legal violation. ${ }^{16}$ In sum, the politicisation of domestic law runs parallel with the perceived politicisation of the High Court.

It is 'the picking of every comma' that alludes to the a 'legal pragmatics', in which opposing sides find administrative and lawful ways of 'doing' and 'undoing' law from within law. Whereas 'legal pragmatics' can be seen as a way in which legality protects refugees by giving them legal arguments, it can also be seen as a way to stop them by creating new legal requirements that narrow the definition of 'genuine' refugee-hood. Humanitarian rhetoric is central to these operations and, again, is used on both sides of the political spectrum. As MacDonald makes clear in his view of the High Court, it is important in the name of real refugees (read: those who in an orderly manner queued up to register with the UNHCR) that this irregularity is dealt with conclusively. Or, in other words, if the High Court

\footnotetext{
${ }^{15}$ Available at http://www.theguardian.com/australia-news/2014/nov/14/ian-macdonald-asylum-seeker-law-changes-aimedavoiding-avoid-high-court (accessed 29 May 2018).

${ }^{16}$ One of the significant cases where international law had a decisive impact was the decision on the proposed agreement with Malaysia; see Plaintiff M70/2011 v. Minister for Immigration and Citizenship and Plaintiff M106 of 2011 by His Litigation Guardian Plaintiff M70/2011 v. Minister for Immigration and Citizenship [2011] HCA 32, available at http:// www.hcourt.gov.au/cases/case-m70/2011 (accessed 29 May 2018). See also CPCF v. Minister for Immigration and Border Protection and Minister for Immigration and Citizenship v. SZQRB [2013] FCAFC.
} 
would not stand in their way (by picking every comma), then real (and deserved) refugees would have better access to the country.

One of the measures that narrowed the definition of refugee-hood involved an amendment to the notion of 'well-founded fear'. The proposed alteration articulated that the fear must relate to the whole country. In other words, an applicant must show country-wide persecution - a requirement not expected from the refugee convention. The amendments have been proposed in direct relation to Australian High Court cases (as well as cases in foreign jurisdictions such as the US, Canada and New Zealand) where outcomes have been in favour of the applicants turning over decisions made by full federal courts. The spatio-legal clause gives further evidence to a 'legal pragmatics' by merely changing the territorial requirement in which 'well-founded fear' is experienced. The principle of 'well-founded fear' remains intact. The act, then, remains committed to the spirit of the Geneva Convention, albeit simultaneously intervening in a key aspect of it.

Critics would simply say that this dynamic concerns a classic instance of finding loopholes in law in order to pursue one's own political interests. Although not unsympathetic to this critique, we are interested in the pragmatic (and moral) structures of these loopholes: what does it mean when law tries to find out what the law can get away with as legal? There is an apparent reason why holding onto the letter - despite violating its spirit - remains essential for Australia's credibility. Nonetheless, their active attempts to find loopholes in law hollows out the essence of the law and breaches law's internal morality.

The work of Lon L. Fuller (1969) attends to such an internal morality. In The Morality of Law, he lays out eight core principles that together comprise the 'internal morality of law': law should be 'general, publicly promulgated, clear, non-contradictory, possible to comply with, relatively constant through time, non-retroactivity, and that there be congruence between official action and declared rule' (Rundle, 2016, p. 500, quoting Fuller, 1969, p. 41). In this respect, one could argue that the inner morality of international refugee law is currently being hollowed out in domestic applications. Through the act, the Geneva Convention is stripped bare of its core principles: it is not clear anymore how it should be adhered to, its core subject - the refugee - is contradictory or ill-defined, there is abuse of retroactive legislation and, finally, there is a failure of congruence between the rules announced and their actual administration. According to advocates of Fuller's framework, this 'hollowing out of law' does not simply mean that the result is a bad form of law. Rather, it suggests that it is not law at all. ${ }^{17}$

Nonetheless, until loopholes are fixed via new judgments, precedents or new legislation, it is the legal legitimation that permits loopholes. What we would like to emphasise with the term 'legal pragmatics' - in addition to Fuller's internal morality of law - is not only that the legitimation processes operate through internal boundaries of law, but also that they produce new meaning and norms. 'Legal pragmatics', then, should be understood as the turf on which the executive and the judicial powers legitimate their positions: the playing field in which the content and meaning of principles and laws are debated, but also are re-established. It is through the act that the status and definition of refugee-hood is disputed. For both the state and the courts, the contestation follows binaries of inand exclusion. As we will explain in the next sections, the criminalisation of the refugee by the state and the juridification of the refugee by the courts form the normative effects of legal pragmatics. This legal discourse on refugees stigmatises some people and groups as criminal and threatening, just as it purifies others as real and deserving.

\section{Neoliberal states and the criminalisation of refugees}

Australia has always presented itself outwardly (and particularly in relation to its neighbouring Asian countries) as a state that strongly upholds principles of human rights, humanitarianism and the rule of law. For the past few decades, however, the topic of asylum functioned as a lightning rod to parties

\footnotetext{
${ }^{17}$ See Rundle (2016) and Waldron (2008).
} 
across the political spectrum and led to stroppy positions vis-à-vis humanitarian allegiances. Whereas, in the 1980s, refugees from Eastern Europe and Asian communist countries such as Vietnam and Laos were welcomed as dissidents and seen as valuable to the moral fabric of the nation, today's refugees from Africa and the Middle East are instead seen as so-called 'bogus refugees' who strip the nation of its resources and jeopardise the welfare state. Despite the highly mediatised language of 'threat' and 'fear' that come with the 'flood' of refugees, humanitarian rationales remain important in justifying restrictive policies.

This is particularly evidenced in the language of deterrence. Deterrence scripts can follow the more neoliberal language of incentives and disincentives, risks and benefits, advantage and non-advantage, and at the same time deploy a humanitarian approach to deterrence, making the distinction between irregular arrivals and illegal people smugglers (Pickering and Weber, 2013). The amendments culminating in the act attend to such a politics of deterrence and confirm a recent change to the figuration of the refugee, namely that of conflating it with the figuration of the economic migrant. In general, media discourse portrays the figure of the refugee within the context of distant suffering and that of a collective of displaced persons in vast landscapes of emergency tents in dire need of care and compassion. In line with the Geneva Convention, the refugee is defined and understood as evicted from their home or in exile from religious, ethnic or political prosecution. They are morally distinguished from 'economic migrants', deserving exceptional attention and treatment because of their precarious and vulnerable position.

In contrast to sentimentalised and 'humanized' media representations of displaced people 'out there, ${ }^{18}$ refugees that cross international borders are redefined as always-already suspicious. In Australia, the terms 'bogus refugee', 'queue-jumper' and the more general 'boat people' help to construct the 'asylum seeker' as insincere and deceitful at best and fraudulent and criminal at worst. Such constructions distances emotion and lessens a need for compassion. Symptomatically, then, some states in the Global North are de-sentimentalising refugees or 'effacing' refugees, which refers to the growing evidence that Western liberal democratic states intentionally withhold journalists and human rights workers from making photographs from asylum seekers, thereby erasing their plight (James, 2014). ${ }^{19}$ In Australia, numerous images are reproduced of suffering refugees in UNHCR tents in unnamed African, Asian or Middle Eastern sites, but the refugee knocking on the door of the state to ask for asylum does not enter the Australian representational field anymore. This suggests a clear departure from how politics used to distinguish between the 'real refugee' and the 'mere migrant'. The refugee far away is now the 'real refugee', while the asylum seeker who makes it to our door is seen as a queue-skipping 'mere migrant. ${ }^{20}$

What does come into the imagination of people are the myriad of substantive assumptions that come with the procedural term of 'illegal' and 'asylum seeker'. Within a deterrence logic, 'illegals', 'asylum seekers' and 'irregular arrivals' are imbued within the stereotype of the 'poor, brown, and destitute' (Dauvergne, 2008). The reason for omitting to humanise asylum seekers has, of course, a hidden but commonly rationalised reason, namely that states want to avoid a confrontation with their publics when carrying out their actions and policies of deterrence. When refugees are portrayed as suffering and in need of protection, as set out by international conventions, their justifications for deterrence are overruled. While the migration system allows the sovereign state to decide who is and who is not allowed to become a citizen in the country, the moral force of international refugee law narrows the powers of the state to block people whom they deem of no interest to the benefit of the country.

The act, then, redraws the contours and conditions of 'real' refugee-hood and criminalises other refugees who do not fall within these categories. In the Australian case, 'real' refugees are limited to

\footnotetext{
${ }^{18}$ In a depoliticised and dehistoricised manner as described by Malkki (1996).

${ }^{19}$ This is less apparent for countries in the Mediterranean such as Italy and Greece, since they are confronted with direct flows of refugees. Australia's deterrence strategies prevents refugees from arriving at the mainland in the first place and are therefore much more easily effaced.

${ }^{20}$ Many thanks to one of the anonymous reviewers for referring us to this point.
} 
the anonymous crowds of innocent people in UN tent camps ('out there') who require urgent care, though wait patiently (and orderly) to access international assistance that can bring them to a safer place. Those who skip the queue are deemed deceitful and therefore undeserved of legal status. In a literal sense, the 'real' refugees, as understood by the act, are those who are prosecuted throughout the country, who are prosecuted even if they would change their occupation and who are prosecuted even if they would modify their behaviour. In other words, the conditions of 'well-founded fear' is put back on the actions and responsibilities of the individuals themselves. Rather than understanding refugees as being exiled out of their country, the act approaches them as active agents in their own predicaments.

This is interesting in light of 'exceptions' that can be observed in asylum policies elsewhere. Child asylum, for instance, receives an exceptional standing in many countries, often leading to moral appeals to treat children differently than the gross of asylum seekers. The Global Child - as the sentimentalised subject with no agency - is seen as embodying separate rights and assigned moral compassion by its sheer status of dependency. ${ }^{21}$ Another instance is the way in which gender and sexuality play an exceptional role in asylum politics. In the Netherlands, for instance, a strong moral force demands recognition for refugees who have fled their country because of their sexual orientation (De Leeuw and van Wichelen, 2012; Fassin, 2010). In France, female genital mutilation suddenly became a dominant inclusion principle and eventuated in a surge of refugees from Sudan (Fassin, 2013). Finally, the ill body too can serve as the exceptional vector in asylum cases. Through the so-called illness clause in France, the ill body has become a humanitarian condition under which to allow people residency (Ticktin, 2011). ${ }^{22}$

What we can draw from these comparisons is that the definition of the 'real' refugee is more and more dependent on (fixed) identities or biologies. So being a child, a woman, a homosexual or someone with an ill body becomes the site of truth. They are given exceptionality because they cannot do anything to change their being - they are that which is prosecuted. The act in Australia illustrates this same tendency by defining conditions of refugee-hood as having to be unchangeable. This is not entirely surprising, since 'immutability' has always been key in civil rights struggles. However, it is now being stressed at the same time that the political figure of prosecution is made malleable. By suggesting that the asylum seeker can maybe move places, change occupations or modify behaviours, s/he becomes - ironically - less relevant in the acquisition of refugee-hood. On the contrary, malleability becomes proof of fraudulence and feeds the eventual criminalisation of refugees.

The point is that domestic particularities to border control are endorsed in domestic courts and the legal operation of determining refugee status is moulded into an administrative process that allows domestic limits to the understanding of suffering. This creates a paradoxical situation. On the one hand, the judicial and administrative practice of processing asylum seekers defines the human subject in universal legal terms - often stripping them of their context and history. The vernacularisation of international law, on the other hand, allows one's own politics of border control to be enshrined in legal processes. Hence, while the refugee in international law is universalised, s/he becomes particularised in domestic law. This is evident in the act's proposal to eliminate references to international law in domestic law.

It is ironic - though inherent to the mechanisms of cultural binaries - that the increased mistrust in asylum seekers informed by measures such as the act also contributes to the increased value of asylum to justify this stance (see also Fassin, 2013, p. 47). In this way, northern states are able to argue that they are 'un-signing' from refugee conventions in order to actually live up to what they signed up for.

\footnotetext{
${ }^{21}$ Scholars have argued, however, that their dependency on their kin is conveniently erased and replaced by the care of the host-state (van Wichelen, 2015; Bhabha, 2009).

${ }^{22}$ Nonetheless, while asylum seekers have succeeded in securing residency on the basis of their diseased bodies (that are thoroughly screened by medical doctors and their apparatuses), their existence in the host country is narrowly defined by this somatic status. As such, while they are provided with medical care, they are not allowed to work, to undertake overseas travel or to apply for family reunion. Their existence is based on their sickness, their citizenship status on biology.
} 
While remaining within the boundaries of the law, liberal legality is turned against what was thought to be its liberal promise. The result is that we can in fact only morally - and not legally - base ourselves on human rights and humanitarianism. Such a paradox also informs the judiciary and their apparatus of human rights organisations. Confined to liberal legality, institutions defending international refugee law necessarily draw on the juridical humanisation of refugees to argue for inclusion.

\section{Human rights and the juridical 'humanisation' of refugees}

The act has been met with great critique. As such, human rights scholars and organisations - in particular organisations specialising in refugee law - have reacted strongly to the act by publicly stating their incompatibilities or breaches with international law. ${ }^{23}$ The president of the Human Rights Commission, Gillian Triggs, voiced her concern in a public statement and specified that the Bill raised serious problems for the rule of law in Australia:

'We are deeply concerned that the legislation is a very deliberate attempt to exclude international law and deprive the high court of a basis to analyze the migration act by reference to international law. ${ }^{24}$

The critiques voiced by these groups attend to what you could call the moral force of international law and the legal community of refugee lawyers. They hold the government accountable and counter governmental strategies of finding legal loopholes that can assist their policies.

As noted by the legal anthropologist, Fleur Johns, 'A notion has prospered among refugee lawyers that international law relating to refugees tends to operate as a restorative, tempering or disciplinary influence upon immoderate state action (or inaction) in this context' (Johns, 2004, p. 587). International law, then, is often summoned as an institution that restraints and corrects the sovereign state in the name of universal human rights. Along with Johns, however, we argue that international law is as much a producer of instincts associating migration with pathology, as it is their ostensible therapy' (Johns, 2004, p. 588). Hence, as Fassin indicates in the case of French immigration politics, 'criminalization and humanitarianization do not simply function as alternative policies ... [ $\mathrm{t}$ ] hey often operate in a dialectical way' (2013, p. 50). Fassin illustrates this by describing how the French state combined both repression and compassion in the treatment of refugees, displaced persons and forced migrants. Similarly to this approach, the Australian state attempts to mitigate the flow of refugees against the asylum seekers' loss of credibility by deterring most of them through repression, while accepting some of them with compassion. Our demonstration of 'legal pragmatics' points to such a dialectical relationship between the executive and the juridical powers, and the way in which their dynamic is constitutive of a certain form of biopolitics.

Without dismissing the importance of human rights critiques, it is important to point to some of the limitations that a 'self-referentiality' of law brings to the politics of asylum. With 'selfreferentiality', we mean that human rights lawyers and their advocates tend to rely on law as a closed system 'which produces and reproduces its own elements by the interaction of its elements' (Varela et al., 1974, p. 187, quoted by Teubner, 1984, p. 292). Here, one seems to always 'get away' with

\footnotetext{
${ }^{23}$ See e.g. reactions from the UNHCR, available at http://unhcr.org.au/unhcr/images/2014\%2009\%2026\%20-\%20Statement \%20-\%20Migration\%20and\%20Maritime\%20Power\%20Legislation\%20Amendment\%20Bill.pdf (accessed 29 May 2018); from the Refugee Council of Australia, available at http://www.refugeecouncil.org.au/n/mr/140926_AsylumLegacyBill.pdf (accessed 29 May 2018) and from the Andrew and Renata Kaldor Centre for International Refugee Law (UNSW), available at http://www.kaldorcentre.unsw.edu.au/sites/kaldorcentre.unsw.edu.au/files/legislative_brief_migration_amendment_resolving_ the_asylum_legacy_caseload_final.pdf?utm_source=Kaldor+Centre+Mailing+List\&utm_campaign=0e1f7555e5-Weekly_News_ Roundup_20+June\&utm_medium=email\&utm_term=0_c5bfc89936-0elf7555e5-145757569 (accessed 29 May 2018).

${ }^{24}$ Available at https://electionspeeches.moadoph.gov.au/speeches/2001-john-howard (accessed 29 May 2018). The Refugee Advice and Immigration Centre's David Manne similarly stated that the Bill represented 'a wholly unwarranted and radical departure from the rule of law in Australia' and was an 'isolationist and parochial approach'.
} 
law, hence the frustration felt by the executive powers that lawyers 'pick every comma in the wrong place to allow someone in', as specified by the quote presented earlier in the article.

The self-referentiality of law strengthens an overall juridification of society. More and more people do not debate a conflict or injury; they see each other in court (Blichner and Molander, 2008). The management of life, institutions and politics has become entrenched in legal contracts and the proliferation of contracts in the world of border security shifts the issue of accountability to a neoliberal and globalising market rather than to an accountable state (Feldman, 2011; Menz, 2009). Besides limiting the responsibility of government, the growing hegemony of legal orders - as explained by John Comaroff - tends to also:

'criminalize race, poverty, and counter politics, in part by outlawing the salience of social cause or consequence; that subject what were once every day democratic processes to the finality of judicial action, thereby juridifying politics to the exclusion of other forms of social action; that displace the 'hot' sovereignty of the people into the 'cold' sovereignty of the law; and that treat all citizens as rational, self-interested, rights-bearing actors and the world as a community of contract.' (Comaroff, 2011, p. 145)

This is not a new observation. The juridification of society has been observed in the US since the 1980s and the perspectives do not privilege a particular political side. ${ }^{25}$ Yet, while these observers remain within the realm of law, the Comaroffs direct our attention to what happens beyond the courts. It is essential to recognise for instance, that humanitarian rationales allowed the global security apparatus to operate legally. Hence, while humanitarianism has at its core principle the humanisation of people, it is also capable of producing harmful effects despite or because of humanisation. Reports have indicated how refugees fleeing persecution of violence have felt betrayed when confronted by the pernicious effects of the immigration system of countries where they stop to apply for asylum. The mistrust and criminalisation inherent to the process of humanisation for asylum seekers (Pickering, 2005; Fassin, 2013) allow the rule of law to be capable of producing as well as justifying its own violence. $^{26}$

The legal process of humanisation in international law, much like the affective forms of compassion in media or the political form of appealing to humanity in governance, can be seen as a technology of 'humanitarian government' (Fassin, 2007, pp. 149-159) that produces a relationship of subjection between the non-liberal subject of the refugee, the asylum seeker, the (irregular) migrant and the noncitizen on the one hand and the universalised liberal citizen-subject on the other. Western humanitarianism, then, as it is inscribed in international law, operates as an effect of legal pragmatics. Such effects figure prominently in labouring the work of domestic politics into domestic law and what happens now is that culture and humanitarian sentiment are juridified in domestic legal processes, thereby undoing international law on behalf of the state.

In the highly securitised world of global migration regimes, law produces the very subject of humanity. This technology of law resonates with colonial technologies of law described by Samera Esmeir in her work, Juridical Humanity, which is situated in colonial Egypt. Esmeir rejects the juxtaposition that colonialism destroys and dehumanises while law regenerates and restores. Instead, locating the production of the human subject within the law itself, she examines how law functions as a vehicle of violence and domination (Esmeir, 2012, p. 8). Her work demonstrates how the human emerged as a juridical category: 'an effect and outcome of modern law that sought to humanize Egyptians by declaring them subjects of the rule of law' (Esmeir, 2012, p. 4). We can argue in the humanitarian present that Western states are doing the same thing with non-liberal subjects as they come into liberal democratic countries in the Global North. There is, then, a post-colonial

\footnotetext{
${ }^{25}$ Many thanks to one of the anonymous reviewers who pointed us to earlier discussions on juridification in the US by legal scholars Mark Tushnet and Mary Ann Glendon representing opposite sides of the American political spectrum.

${ }^{26}$ See also how this translates to colonial law (Esmeir, 2012).
} 
dimension to the pragmatics of law. And this moment can be traced back to the very beginning of the formation of the Geneva Convention, when representation of countries from the Global South was very restricted. ${ }^{27}$ Notably, by limiting the notion of the refugee - and, by extension, of the human - to a juridical understanding, other notions of refugee or humanity are excluded.

This is not to say that law is merely a technology of neo-imperialism or neocolonialism. Rather, as explained by Esmeir in the context of modern law in the time of colonialism, 'extreme violent measures were the vehicle for the production of a sphere of idealized juridical humanity; idealized humanity produced its own violence in order to safeguard the authority of its ideals' (Esmeir, 2012, p. 282). Returning to the act, we can say that the criminalisation of the refugee enabled the production of the 'real' refugee. Hence, while we can approach and critique this development as a form of epistemic violence, it also provides us with the normative foundations in which to voice these injustices. It is therefore paramount that we do not see politics and law as opposing or closed systems, for the criminalisation of the refugee is intimately connected to the humanitarianisation of the refugee, operating dialectically in shrewd and effective ways.

\section{Conclusion}

It is without doubt that the topic of asylum is among the most pertinent topics fuelling debates in the Global North today. While care is taken to differentiate between refugees and migrants, the situation in many countries reveals the extent to which this distinction is untenable. Men, women and children flee war, conflict and state repression, but they also flee poverty and unemployment - dire situations that are entangled with grander mechanisms of global capital. It is pertinent, therefore, to see the current 'refugee crisis' not only as the product of domestic mayhem in the Global South, but also as a phenomenon tightly linked to the economies and histories of the Global North (Feldman, 2011; Bhambra, 2010; Comaroff and Comaroff, 2012; Ferguson, 2015). The politics of 'un-signing' seems to be symptomatic of states unwilling to seriously grapple with the reality of many refugees who flee countries for a variety of reasons, including those brought about by global inequality.

The combination of an intensified border control with an increasing appeal to humanitarian justifications characterises a contemporary legal playing field in which the 'real' refugee is continuously under definitional scrutiny and fought via conflicts of domestic with international law. The quotes at the onset of this paper illustrate how this currently operates in Europe, demonstrated by the Brexit events in the UK, and in Northern America, illustrated by Trump's attempts to limit the number of refugees in the US. Australia, then, is no exception, and the legal pragmatics emerging in the playing field between the executive and judiciary powers reveal the structural features of a neoliberalising law symptomatic to countries in the Global North.

We question the solution offered by some human rights activists and scholars that the only way to tackle the asylum question is to establish a more rigid global governance structure that regulates asylum on a truly global scale (see e.g. James, 2014). Resolving the global asylum problem with a global or regional covenant, for instance, might make the regulation of asylum more manageable on a global scale, but it will also contribute to a further juridification of the refugee body. Put in another way, remedying effects of law with more of the same law will do more to worsen the problem rather than to solve it.

However, our position does not lead to an automatic dismissal of a legal system, nor does it propose a position outside of law's conventions by advocating new universal utopias. Our modest aim was to merely point out that the current legal system of human rights, and the humanitarian reason informing its foundations and operations, are not based on an idea of interdependency. Instead, the apparatus of legal authority helps to sustain the principle of the autonomous individual alongside the principle of the sovereign state. This all works fine when cosmopolitan ideas prevail, and such legal systems give

\footnotetext{
${ }^{27}$ Although Columbia, Venezuela, Brazil, Iraq and Egypt were included, other countries from the Global South were excluded or had very limited representation in the discussions and legal formulations.
} 
rights and make citizens. The conditions in late modernity, however, are such that the very same system - including its humanitarian justifications - are being deployed to take away rights, to bar residency and - in these anti-terror times - also to confiscate citizenship. As long as the Global North is invested in her liberal belief of enlightened progress and modernity, it will never completely 'un-sign'. At the same time, the ethic of care will not be a product of solidarity, but instead a pragmatic effect of the legal technologies of humanitarian government.

Acknowledgements. This paper was based on a paper delivered in the workshop 'New Spirits of Humanitarianism' organised by the Institute of Culture and Society and the Philosophy Department at Western Sydney University in 2014 and the panel 'Theory and Practice of Human Rights' at the 2016 Annual Meeting of the International Society of Public Law (ICON-S) in Berlin. The authors would like to thank the panellists and commentators at these events, as well as Jessica Whyte, Jane McAdams and Arthur Glass for their critical commentary on earlier versions of this paper. They would also like to thank the anonymous reviewers for their thoughtful comments and suggestions.

\section{References}

Bhabha J (2009) Arendt's children: do today's migrant children have a right to have rights? Human Rights Quarterly 31, 410-451.

Bhambra GK (2010) Historical sociology, international relations and connected histories. Cambridge Review of International Affairs 23, 127-143.

Blichner LC and Molander A (2008) Mapping juridification. European Law Journal 14, 36-54.

Comaroff J (2011) The end of neoliberalism? What is left of the left. Annals of the American Academy of Political and Social Science 2011, 141-147.

Comaroff J and Comaroff JL (2012) Theory from the South: or, how Euro-America is evolving toward Africa. Anthropological Forum 22, 113-131.

Crock M and Bones K (2015) Australian exceptionalism: temporary protection and the rights of refugees. Melbourne Journal of International Law 16, 522.

Dauvergne C (2008) Making People Illegal: What Globalization Means for Migration and Law. Cambridge: Cambridge University Press.

De Leeuw M and Van Wichelen S (2012) Civilizing migrants: integration, culture, and citizenship. European Journal of Cultural Studies 15, 195-210.

Esmeir S (2012) Juridical Humanity: A Colonial History. Stanford: Stanford University Press.

Fassin D (2007) Humanitarianism, a nongovernmental government. In Feher M (ed.), Non-Governmental Politics. New York: Zone Books.

Fassin D (2013) The precarious truth of asylum. Public Culture 25, 39-63.

Fassin E (2010) National identities and transnational intimacies: sexual democracy and the politics of immigration in Europe. Public Culture 22, 507-529.

Feldman G (2011) The Migration Apparatus: Security, Labor, and Policymaking in the European Union. Stanford: Stanford University Press.

Ferguson J (2015) Give a Man a Fish: Reflections on the New Politics of Distribution. Durham/London: Duke University Press.

Fuller LL (1969) The Morality of Law. New Haven: Yale University Press.

James P (2014) Faces of globalization and the borders of states: from asylum seekers to citizens. Citizenship Studies 18, 208-223.

Johns F (2004) The madness of migration: disquiet in the international law relating to refugees. International Journal of Law \& Psychiatry 27, 587-607.

Malkki LH (1996) Speechless emissaries: refugees, humanitarianism, and dehistoricization. Cultural Anthropology 11, 377-404.

Menz G (2009) The neoliberalized state and migration control: the rise of private actors in the enforcement and design of migration policy. Journal of Contemporary Central and Eastern Europe 17, 315-332.

Pickering S (2005) Refugees and State Crime. Annandale, NSW: Federation.

Pickering SJ and Weber L (2013) Hardening the rule of law and asylum seekers: exporting risk and the judicial censure of state illegality. In Stanley E and McCulloch J (eds), State Crime and Resistance. Abingdon: Routledge, pp. 183-198.

Rundle K (2016) Fuller's internal morality of law. Philosophy Compass 11, 499-506.

Teubner G (1984) Autopoiesis in law and society: a rejoinder to Blankenburg. Law \& Society Review 18, 291-301.

Ticktin M (2011) Casualties of Care: Immigration and the Politics of Humanitarianism in France. Berkeley: University of California Press. 
van Wichelen S (2015) Scales of grievability: on moving children and the geopolitics of precariousness. Social \& Cultural Geography 16, 552-566.

Varela FG, Maturana HR and Uribe R (1974) Autopoiesis: the organization of living systems, its characterization and a model. Biosystems 5, 187-196.

Waldron J (2008) The concept and the rule of law. Georgia Law Review 43, 1.

Cite this article: de Leeuw M, van Wichelen S (2019). Un-signing Geneva: legal pragmatics in the management of asylum. International Journal of Law in Context 15, 20-32. https://doi.org/10.1017/S1744552318000113 